\title{
Troubling the psychosocial: Jock Young's late modern subjectivity from Sartre to Marcuse
}

Theoretical Criminology 2014, Vol. 18(4) 450-458 (C) The Author(s) 2014 Reprints and permissions: sagepub.co.uk/journalsPermissions.nav DOI: $|0.1|$ |77/| 3624806/4557206 tcr.sagepub.com @SAGE

\section{Sara Salman}

The City University of New York, USA

Jock Young's well-known trilogy The Exclusive Society (1999), The Vertigo of Late Modernity (2007), and The Criminological Imagination (2011) signals a turn from criminological theories that have historically divided the individual and the social, the symbolic and the material, the affective and the rationalistic, and the 'subjects' and 'objects' of research. For Young, the social sciences are in crisis, replete with positivism, banality and one-dimensional scholarship. Young's radical anti-positivist critiques are well known; less analyzed if equally bold are investigations of social and psychic dynamics that pervade his trilogy. As articulated most forcefully in The Vertigo of Late Modernity (2007), Young diagnosed deep emotional uncertainties corresponding to glaring structural inequalities and repression in late modern society.

Young, a founding figure of both critical criminology and cultural criminology, tends to be associated with a number of intellectual traditions including Marxism, the Birmingham School, and the political sociology of C Wright Mills. However, Young's trilogy points to intellectual connections beyond these schools of thought that may have been obscured by his resistance to Freudian metapsychology. Despite his interest in connecting social structures and internal psychodynamics like anxieties and 'panics', Young is not regarded as a psychosocial theorist. His decidedly anti-Freudian position puts him at odds with the Frankfurt School's joint psychoanalytic and Marxist commitments all the while he shared the School's interest in linking internal subjective dynamics and objective structures of modernity. But theoretical connections exist, even though they have rarely been explored.

\section{Corresponding author:}

Sara Salman, The Graduate Center, The City University of New York, 365 Fifth Avenue (at 34th St), New York, NY 10016, USA.

Email: ssalman@gc.cuny.edu 
I contend that Young had an ambivalent relationship with psychosocial theories. Having been his student, I know that he both encouraged reading Freud and articulated suspicions about deterministic concepts like the 'id' and the 'unconscious'. Why did Young express doubt about psychosocial explanations even as he emphasized the significance of emotional experiences? And, given this, how can we read his work on the psychodynamics of late modernity? Despite Young's reluctance to embrace Freudian categories, his work should not be removed altogether from either the Frankfurt School or more recent psychosocial thought. Rather, it is argued here that important connections persist between Young's theoretical framework and existential psychology that can be traced back to Jean-Paul Sartre's phenomenological approach to subjectivity and to the Frankfurt School's psychosocial theory particularly as developed by Herbert Marcuse.

In this essay, I explore Young's contentious relation with psychosocial theory by first focusing on The Vertigo of Late Modernity (2007), a theoretical work that examines the social condition of late modernity and its emotional tolls. Here Young introduces a new issue: the subjective dimension of the late modern experience. He explains crime, social policies, and acts of war in terms of objective social structures and corresponding human emotions like anxiety and antipathy. For Young human action is incomprehensible apart from its simultaneously social and psychic underpinnings. Second, I argue that although Young's work has a strong psychodynamic dimension, he relies on Sartrean phenomenological explanations of human action rather than Freudian psychoanalytic ones. While Sartre was critical of Freud, his work nonetheless inspired an existential brand of theorizing that addressed some of Young's antipathy to essentialist psychoanalytic concepts without doing away with human subjectivity. For Young, a Sartrean orientation allows for historical transformation to be realized by conscious actions, which are nonetheless fraught with 'psychosocial' emotions such as existential anguish. In this framework, unconscious motivations neither prevent nor determine action. Third, I show a generally unrecognized affinity between Young's position on human subjectivity vis-a-vis social structures and Herbert Marcuse's position on liberation, as presented most forcefully in Eros and Civilization (1966/1955). Young's analysis of othering, which connects subjective experiences with specific socio-historical moments wherein they arise, expands upon Marcuse's psychosocial oriented work on human liberation in late capitalism. Finally, given the pioneering and lasting significance of Jock Young's intellectual contribution to sociological and criminological theory, I return to the importance of recognizing rather than obscuring that work's psychosocial dimension.

\section{Late modernity and the psychosocial}

Young began his trilogy by outlining material and cultural changes that have taken place globally since the 1970 s in the period he calls 'late modernity'. The period is marked by a shift from security provided by work, family and community to uncertainty which comes with the casualization of employment and disintegration of traditional social formations. It is characterized by massive socio-economic changes: manufacturing is outsourced to the developing world while home-grown technologies replace human labor in the advanced world, turning western economies toward financialization. Moreover, the period is characterized by the rise of structural unemployment, declines in real wages, 
and the rise of dual-income families. The middle class, once a robust segment of social democratic societies, has been shrinking - accumulating debt and clinging to precarious employment - while the poor are worse off, overworked, underpaid, and systematically targeted by exclusionary policies. Finally, technological advancements in transportation, telecommunication, and mass media bring the cultures of the world much closer to one another, turning what used to be a homogenous public sphere into a heterogeneous space marked by a plurality of cultural values. These changes produce the 'chaos of reward and identity' whereby work, family, and community cease to be sources for material reward and social identity (Young, 1999, 2007).

One may argue that these phenomena are not new: 19th-century capitalism brought similar disruptions to social formations. However, the swiftness with which these changes have taken place in late modernity makes them qualitatively different. Flexible work, the dual income household, and migration altered everyday life in western as well as non-western societies. The technological revolution makes cultural exchange an uninterrupted flow of messages across the world. The late modern condition is global in its scope. Furthermore, the impossibility of a uniting narrative and the dissenting voices of women, queer, and post-colonial peoples all contest the once hegemonic discourse of modernity. In this regard, late modernity is conceptually similar to postmodernity.

However, the two concepts differ on questions of subjectivity and liberation. Postmodernists argue that human beings are always already interpolated by the social world in which they live. As such, postmodern thinkers tend to focus on the structures that interpolate people, rather than the latter's subjectivities. In addition, postmodernists argue that we cannot escape mediation and representation; our world is mediation and representation, and our concepts are always already determined by social structures. This leaves us with no possibility for change. Postmodern thinking has little room for dialectical contradictions, speaking predominantly of indestructible structures.

This is a defeatist formulation for Young (2011: 218), who describes it as 'mission impossiblism'. Unlike postmodernity, the concept of late modernity sees a dialectic in our hyper-plural world. It recognizes how seemingly unshakeable structures such as the state and capitalism have contradictions that present the possibility of their collapse. In addition, human beings have subjectivities that cannot be encompassed entirely by social structures; subcultures and even crime are expressions of disruptive subversion (Young, 2007: 72). Young develops the concept of late modernity to include both structural changes and how individuals act in relation to such changes. Therefore, 'late modernity' reveals human subjectivity as a force for transformation.

\section{The problematic in Freudian metapsychology}

Young's insistence on transformative, and thus historical, subjectivity may explain his complex relationship with psychoanalysis. It is curious that Young (2007: 39) describes othering in late modernity as 'narcissism of minor differences'. Notably, the term appears in Freud's Civilization and its Discontents (1961) to explain human aggression. For Freud, this is a trans-historical tendency whereby people construct differences through which groups preserve their identities against groups with which they otherwise have much in common. But Young does not accept the trans-historicity of the term. In Vertigo, 
he gives the example of machismo, the performance of blue-collar hyper-masculinity. He notes that this phenomenon intensifies in late modernity, precisely when differences between men and women become less significant - disrupting gendered power dynamics - and working class men lose social status as they become marginal on the job market (Young, 2007: 39-40). In The Criminological Imagination (2011) Young explicitly refutes Freud's use of the term, and notes that such conflicts are acts of aggression occurring at historical moments characterized by the chaos of reward and identity, when differences between groups appear both narrow and costly.

Thus Young does not do away with Freud altogether. For him, the narcissism of minor differences may be a universal human response but not a constant one; rather, it is a tendency that erupts at certain moments and therefore must be historicized to be understood. On the other hand, Freud posits that there is no dialectical tension between human subjectivity and objective structures. In his analysis of sexuality and human civilization, when we are 'acting' we are 'enacting' universal psychic and social transhistorical structures.

Significantly, the absence of dialectic in Freud puts human agency into question. Young is suspicious of Freudian psychoanalysis because it postulates psychic structures, of which we are not aware, that encompass us. The notion that the human psyche is constituted by conscious and unconscious structures could lead one to conclude that there is a split in our psyche - that is, the human mind is not a totality but a collection (Sartre, 1956). It follows that how one feels and acts are both largely formed by unconscious forces, which cannot be accessed, making one's actions a result of motivations other than his or her own consciousness. Such analysis typically sees unconscious motivations as more 'authentic' while our conscious motivations appear as 'falsehoods' (Catalano, 1974; Sartre, 1956). Freudian psychoanalysis undermines human freedom. It brings us to an essentialist explanation of human action which denies the possibility of liberation through transformation.

This is problematic for Young. His theoretical position throughout his work, and especially in his trilogy, is that humans make their history however constrained they may be by objective structures. This is what makes transforming the world conceptually possible. Young departs from Freud's metapsychology because he does not see it as allowing for dialectical transformation through the subjective overcoming of social structures. Trans-historical Freudian categories negate the possibility of historical change. Young $(2007,2011)$ instead adopts a phenomenological dialectical lens, and argues that understanding and acting in the world are contingent upon our perceptions of and experiences in it.

\section{Marcuse, liberation and bad faith}

Young's treatment of Freud is an attempt to bring the psychosocial into the fold of critical social theory by way of existentialism. Young does not reject the language of psychodynamics that, in his writings, helps to explain human actions from petty crime to torture. However, he is critical of separating emotions and desires from human consciousness, and from the historical context in which they exist. Again, for Young, the problem with Freudian metapsychology is that it constructs a world of apparent inevitability. In 
Civilization and Its Discontents (1961), Freud posits that repression is necessary to preserve civilization because, left to their own devices, people would simply pursue the pleasure principle and seek pleasures unrelated to survival. Repression ensures that the reality principle, the need to work and avert scarcity for the survival of the species, is maintained. Repression includes the internalization of the necessity of work and sublimation of our creative and destructive drives to stabilize social formations (1961: 9899). ${ }^{1}$ Freud (1961: 96-99) explains wars and other forms of structural violence as the result of excess human aggression that cannot be contained by sublimation. If we accept Freud's argument we arrive, according to Young, at inescapability and even nihilism.

However, if we insist that categories such as 'scarcity' and 'repression' are affected by the historical changes that human societies have undergone, we could arrive at a much more radical theory of repression and liberation. This is Young's position. For him, structural oppression is historically contingent. It carries within it contradictions that generate various emotional responses and forms of resistance (Young, 2007, 2011). The potential for transgression rests in a dialectical movement between agency and structure. Here, I return to Young's theoretical connection with the Frankfurt School's historically oriented work - especially that of Herbert Marcuse.

Marcuse's project in Eros and Civilization (1966/1955) was to historicize and develop a Freudian metapsychology to offer psychosocial explanations of repression and liberation. This is where Young meets Marcuse intellectually. Young (2007: 4) argues that late modernity is characterized by hyper-pluralism and heightened reflexivity that '[hold] the possibility to a redistributionist approach to social justice and a deconstructive approach to identity'. Late modernity carries the potential for liberation. In Eros (1966/1955) Marcuse argued that the technological advancements of the era did away with material scarcity, making toil unnecessary. As such, we arrive at a historical moment where we can pursue our desires for creativity and being with others, while our material needs for survival are securely met by an advanced system of production. Notably, unlike Marcuse, who emphasizes the role of technology in achieving liberation, Young emphasizes the role of self-reflexivity. But both see the potential for liberation and recognize social misery as the result of unequal distribution of wealth and structural repression. Neither Young nor Marcuse follows Freud's construction of the world as trans-historical.

Indeed, Marcuse historicizes Freudian categories and argues that current forms of repression and scarcity have no rational place in advanced capitalism. The violence we see today is 'surplus repression', which along with contemporary forms of material scarcity, is instituted artificially to maintain the domination of capitalism (Marcuse, 1966/1955: 34-35). However, Marcuse believed that liberation was imminent because repression was bound to lose legitimacy as a means of preserving civilization. He offered a Marxist reading of human history in stages, envisioning liberation as the next step of civilization. Yet, it is precisely this moment of liberation that appears suspended.

In 1966, Marcuse followed up on Eros in a political preface that described a regressive moment in human history. ${ }^{2} \mathrm{He}$ observed that while the conditions for human liberation exist, we have not yet freed ourselves from repressive social structures: revolutions are either crushed or coopted; technology is used to advance domination and destruction rather than freedom and creativity. Marcuse (1966: xxiii-xxv) noted that he had 
underestimated the power of social systems of domination that enact violent repression and ideological cooption via penalizing social policies and the reification of everyday life.

In many ways, Young's analysis of late modernity can be read as an expansion of Marcuse's critique in that it recognize a new form of scarcity: paid work. Today, capitalism offers long work hours, pay cuts, and a new ethos of work that emphasizes 'flexibility', a euphemism for precarious employment. Work once provided both the material basis for survival and the existential basis for identity: under late capitalism, it emerges in a strange form, scarce and unrewarding (Young, 2007: 86). Today, despite its abject failure to deliver material rewards, work remains very much connected to self-realization and takes on a redemptive, almost magical character (Young, 2007: 82). The cultural meaning of work in late modernity constitutes a stubborn force of social repression, in ways that Marcuse perhaps could not have imagined. ${ }^{3}$

Yet, it is not just a matter of a repressive ideology of work. Young turns to existentialist psychology to explain the contemporary regressive moment. Young (2007: 19-20) argues that humans possess the capacity to transcend themselves, leaving them with a multitude of possible courses of action that can be revolutionary or reactionary. Because transcendence exists as a possibility, there is no inevitable path to progress. Young's position evokes Sartre's conceptions of reflexive consciousness and radical freedom, the latter defined as the capacity in the last analysis to choose our actions. Our emotions are not separate from our consciousness; furthermore, we possess reflexive knowledge of them. We recognize that our action at any point may not be the only action we can choose (Sartre, 1956). Young expands on Sartre by positing that late modernity makes reflexivity much more pressing and urgent. Encounters with other cultures in everyday life reveal a pluralism of values: our traditions can no longer stand sacred. As old privileges and moral certainties fade, we realize we have the means through which we can see and be in the world differently. People can challenge monolithic epistemologies through recognition that our ways of knowing the world emerge from our experiences in it: the moment has a liberating potential (Young, 2007: 3-5).

Not so fast, though. Our capacity to transcend is not something with which we easily reckon. Reflexivity and freedom exist as self-questioning of what we have done, are doing, and can do, such that they bring angst (Sartre, 1956). To avoid anguish, we fall on determinisms that serve to relieve us of our 'freedom'. As such, reflexivity can hold 'the possibility of a redistributionist approach to social justice' or 'an acceptance of the world as it is' (Young, 2007: 4). Thus regression in the contemporary world appears connected to experiences of disembededness and profound anomie, both of which generate emotional uncertainties. Late modern hyper-pluralism brings about ontological insecurity, akin to Sartrean anguish.

For Young, there is a catch to such hyper-pluralism. It coincides with drastic socioeconomic changes that have shaken the material foundation of our social formations (Young, 2007: 68). The late 20th century witnessed the collapse of legitimate opportunity structures. We are experiencing the 'chaos of reward', or the seemingly arbitrary ways through which people acquire wealth and status (Young, 2007: 63). This carries the heaviest toll in societies that value meritocratic ideals of hard work. Despite the absence of material evidence, there is still a deeply held cultural belief that hard work pays off. 
We are at a moment of desperation, in vertigo, experiencing 'a sense of insecurity ... and a fear of falling' (Young, 2007: 12). The scarcity of rewarding work hinders liberation by instituting fear of losing the very ground upon which we stand. We are not exercising our freedom because to do so risks losing everything - a dangerous possibility.

It is perhaps no coincidence that Young uses the term 'vertigo' to denote the experience of late modernity. Young (2007: 141) describes the feeling of vertigo as 'the fear of the ever possible loss of status or of downward mobility'. The notion that the loss is 'ever possible' suggests that the fear is not of falling but of making a move that would bring about the fall. In this regard, Young's use of the term shares similarities with Sartre's vertigo. Sartre (1956: 65) used the term to denote the anguish experienced over one's knowledge that one can act in multiple ways: 'vertigo is anguish to the extent that I am afraid not of falling over the precipice, but of throwing myself over'. Indeed, when Young describes antipathies toward the poor, he notes that the outraged are not simply envious of the poor's 'irresponsible' lifestyle, but that they experience fear over their own 'responsible' choices. The choice to work to be an 'included citizen' is at the same time a choice that means 'missing out' on the pleasure of familial and social relations (Young, 2007: 43-44). The precarious middle class is walking a very fine line of selfdenial for fear that any other act risks losing what little it has.

In this case, the experience of self-doubt develops into a violent antipathy against the poor. Because our identity is grounded in work, family, and social connections, all of which become affected by the chaos of reward, we begin to experience the "chaos of identity' (Young, 2007: 35). Deep existential insecurity calls forth the psychodynamic reaction of othering, through which we seek to ground ourselves against the 'loosening of the moorings' by turning our vindictive gaze toward the vulnerable. This is how social repression coopts discontent. Instead of resisting structural inequalities, we turn inward. Instead of risking losing everything, we cling to an essentialized sense of self as 'respectable citizens', and come to desire punitive policies against the unemployed, deviant others (Young, 2007: 42, 62).

As such, othering is not simply the demarcation of social boundaries between groups; it is a psychosocial response to the dizzying experience of chaos. Othering preserves a person's sense of wholeness, coherence and righteousness by constructing the 'other' in a manner that evokes hostility or pity. Rather than realizing the freeing potential of hyper-pluralism, one identifies with fixed categories, and 'the net result is bad faith, a movement away from human spontaneity, reflexivity and action' (Young, 2007: 198). Othering is a form of bad faith; it is the belief that our being is both split from our freedom to transcend and reflect, and identified with structures or roles external to our consciousness. For Young, othering is a reflection of the deep anxieties that coincide with ever-possible freedoms.

Further, terms like 'spontaneity' and 'reflexivity' reveal Young's concern with liberation through consciousness of being. For him, the self is not fixed, and conscious subjectivity is defined by transcending itself as such. In fact, the situation is not entirely hopeless. Young (2007: 54) urges social scientists to recognize that structure and agency constitute one another, and that human action has a subjective dimension that interacts with the structural dimension in ways which are not always easy to capture or coopt: 
In a grotesquely unequal society, resistance is always present whether it is fully fledged opposition or the micro-resistance of attitude or style. Some of it we may not like, some may mirror the othering of the powerful. But resistance is always there.

(2007: 77)

Resistance may not produce desired social changes; it can be reactionary as well as transformative. However, it exists despite overwhelming structural violence. It is a distinguishing trait of human beings to challenge and transform; we have the capacity to orient ourselves toward a future, toward a not-yet.

The not-yet is precisely why Young opts for a dialectical and existentialist framework. He rejects the determinism of Freudian metapsychology for the same reason he rejects 'mission impossiblism' theories: both express bad faith which relieve us of our responsibility to exercise our freedom. Young was suspicious of deferring the question of liberation and of capitulating to external structures that, for positivists, forever exist out of the reach of human consciousness and agency. But Young did not simply do away with the psychosocial. More precisely, he offered both a critical appraisal of psychoanalysis and an alternative theory of emotions and agency. Young's theory of late modern psychodynamics emphasizes human consciousness so as to offer a path to liberation. The latter can only be realized through self-reflexivity and confronting bad faith. For Young, selfreflection allows us to comprehend that we have the capacity to reproduce or disrupt the social order, and that neither is an inevitable course of action. Jock Young's analysis of the psychodynamic underpinnings of human action in his trilogy reveals his preoccupation with the question of what is to be done. As such, Young's engagement with the psychosocial is a part of his intellectual and political project to link theory and praxis.

\section{Funding}

This research received no specific grant from any funding agency in the public, commercial, or not-for-profit sectors.

\section{Notes}

I wish to thank Lynn Chancer for working closely with me on the article, and Sam Connet and Dan Douglas for their editorial suggestions. It would have not been possible without you.

1. It is in this section of the book that Freud articulates the narcissism of minor differences as an outlet for inevitable aggression which maintains group boundaries.

2. The preface was written after the publication of One-Dimensional Man (1964), the book where Marcuse attempts to explain the regressive tendencies of advanced industrial society and what he calls 'the paralysis of critique'.

3. Other social theorists have also addressed the fetishization of work under late capitalism. See, for example, Stanley Aronowitz and William DiFazio (1994) and Andre Gorz (1999).

\section{References}

Aronowitz S and DiFazio W (1994) The Jobless Future: Sci-Tech and the Dogma of Work. Minneapolis, MN: University of Minnesota Press. 
Catalano JS (1974) A Commentary on Jean-Paul Sartre's Being and Nothingness. Chicago, IL: University of Chicago Press.

Freud S (1961) Civilization and Its Discontents. Trans. Strachey J. New York: WW Norton.

Gorz A (1999) Reclaiming Work: Beyond the Wage-Based Society. Cambridge: Polity Press.

Marcuse H (1964) One-Dimensional Man: Studies in the Ideology of Advanced Industrial Society. Boston, MA: Beacon Press.

Marcuse H (1966/1955) Eros and Civilization: A Philosophical Inquiry into Freud. Boston, MA: Beacon Press.

Sartre JP (1956) Being and Nothingness. Trans. Barnes HE. New York: Washington Square Press. Young J (1999) The Exclusive Society. London: SAGE.

Young J (2007) The Vertigo of Late Modernity. London: SAGE.

Young J (2011) The Criminological Imagination. Cambridge: Polity Press.

\section{Author biography}

Sara Salman is a PhD candidate in Sociology at the Graduate Center, City University of New York. Her dissertation research uses comparative analysis to examine citizenship in late modernity. She has also written on war and genocide, nativism and migration, and political unrest in the Middle East. 